\title{
WHEN IS A DONOR A DADDY? INFORMAL AGREEMENTS WITH KNOWN SPERM DONORS: LESSONS FROM ABROAD
}

\author{
Carmel van Niekerk \\ LLB LLM \\ Lecturer, University of the Western Cape
}

\section{SUMMARY}

Individuals are increasingly entering into informal agreements with known sperm donors in order to either circumvent the costs involved in using fertility centres or owing to personal beliefs and preferences. When they do so, the legal protection that ordinarily accompanies the use of a fertility centre is either sparse or lacking. The question is what happens when one of the parties reneges on the agreement, either by demanding parental responsibilities or rights in the case of the donor or, in the case of the recipient, by demanding that the donor assumes a parental role when this was never his intention. The position in South Africa is currently unregulated. This article, therefore, examines the position in a number of foreign jurisdictions with the aim of making recommendations for the way forward in South Africa.

\section{$1 \quad$ INTRODUCTION}

Where sperm is donated via a licensed doctor/fertility centre and artificial fertilisation occurs, a donor acquires no parental responsibilities and rights in respect of the child. ${ }^{1}$ This appears to be the case regardless of whether or not the donation occurred anonymously. ${ }^{2}$ This is the position in most countries. $^{3}$ In this respect, South Africa is no exception. ${ }^{4}$ Under these

\footnotetext{
This position is confirmed in foreign legislation such as the UK's Human Fertilisation and Embryology Act 1990. While s 1 of the South Africa's Children's Act 38 of 2005 (Children's Act) does not specifically make reference to donation via a licensed doctor or fertility centre, the Act defines artificial fertilisation as "the introduction other than [by] natural means of a male gamete or gametes into the internal reproductive organs of a female person for the purpose of human reproduction". This is presumed to exclude sexual reproduction. It is uncertain whether insemination by means of a turkey baster qualifies as natural means, although, in the UK, it has been confirmed that reproduction that occurs in this manner does not qualify as the use of medical technology. See Volokh "The Term 'Medical Technology" Does Not Encompass a Kitchen Implement Such as a Turkey Baster" (21 April 2015) https://www.washingtonpost.com/news/volokh-conspiracy/wp/2015/04/21/the-term-medicaltechnology-does-not-encompass-a-kitchen-implement-such-as-a-turkey-baster/ (accessed 2020-03-06).

2 Luetkemeyer and West "Paternity Law: Sperm Donors, Surrogate Mothers and Child Custody" 2015 112(3) Missouri Medicine 162 163. In this case, the distinction affects the amount of information that the child is entitled to upon attaining majority.

3 Including Canada and most states in the USA.
} 
circumstances, it is acceptable for biological parents to contract away their parental rights. The position is, however, less straightforward where the parties know each other, ${ }^{5}$ and when they reach an informal arrangement and the donation occurs without the intervention of a medical practitioner. In these cases, the legal consequences that ensue are more complex. ${ }^{6}$

This article examines the use of informal agreements in cases of known sperm donation and, in particular, the rationale behind these arrangements. It further examines the legal landscape for sperm donation in South Africa. Thereafter cases that have emerged from various countries involving the use of informal agreements are discussed as well as lessons that can be learnt from these jurisdictions. Suggestions are then made for the possible regulation of agreements with known sperm donors in South Africa.

\section{THE RATIONALE BEHIND INFORMAL AGREEMENTS}

Informal agreements and home insemination are increasingly appealing owing to the high costs involved in engaging the services of a legal practitioner and the costs involved in undergoing in vitro fertilisation, both of which can be circumvented by doing things oneself. ${ }^{7}$ The challenge posed by this is that where parties decide to proceed without the involvement of a fertility centre, the accompanying legal agreements that delineate the roles and responsibilities of the various parties are either incomplete or sparse. As a result, the protection that is ordinarily afforded to the parties is lacking. ${ }^{8}$

Furthermore, there may be some comfort in knowing the identity of the donor or being intimately acquainted with him. ${ }^{9}$ In addition, informal arrangements and natural insemination may be pursued out of beliefs about the quality of fresh sperm as opposed to the frozen kind. ${ }^{10}$ Individuals may also prefer this option because it takes place in a non-clinical environment, with fertilisation occurring within the privacy and comfort of a person's

4 This position is regulated by s 40 (3) of the Children's Act.

5 In some instances, the recipient may merely know the identity of the donor or they may be personally acquainted with the recipient (in the case of a friend) and possibly intimately acquainted (in the case of an ex-boyfriend or lover).

6 Legal disputes typically arise when the donor reneges on the agreement and decides to play a more active role in the child's life. Alternatively, the woman, herself, may change her mind about the role that the donor should play.

7 IVF treatment costs in the region of R74 492.00, although this excludes some of the other costs that may be incurred. See MedFem Fertility Clinic "Treatment Costs" (undated) https://medfem.co.za/treatment-costs/ (accessed 2020-03-06).

8 Harper, Jackson, Spoelstra-Witjens and Reisel "Using an Introduction Website to Start a Family: Implications for Users and Health Practitioners" 20174 Reproductive BioMedicine and Society Online 13 16-17.

9 Silver "Known Donor or Sperm Bank?" (25 July 2016) https://www.elisilvernd.com/healthnews/known-donor-or-sperm-bank (accessed 2019-06-19).

10 McGovern and Schlaff "Sperm Donor Anonymity: A Concept Rendered Obsolete by Modern Technology" 2018 109(2) Fertility and Sterility 230231. 
home. ${ }^{11}$ Personal beliefs regarding the reproductive process thus impact on a decision to follow this route.

\section{THE SOUTH AFRICAN LEGAL FRAMEWORK}

In recent years, South African courts have on at least two occasions ${ }^{12}$ considered questions regarding the position of known sperm donors. The reason that this phenomenon is still uncommon is because gamete (that is, sperm and egg) donation in this country is predominantly anonymous and is processed through a fertility clinic where agreements are concluded beforehand. ${ }^{13}$ Anonymous donation is therefore regulated. The current legal position is provided for by section 41(2) of the Children's Act, which states:

"Information disclosed in terms of subsection (1) ${ }^{14}$ may not reveal the identity of the person whose gamete was or gametes were used for such artificial fertilisation or the identity of the surrogate mother."

The position in section 41 is further bolstered by regulation 19 in the Regulations relating to the Artificial Fertilisation of Persons ${ }^{15}$ promulgated in terms of the National Health Act. ${ }^{16}$ This regulation provides:

"No person may disclose the identity of any person who donated a gamete or received a gamete, or any matter related to the artificial fertilisation of such gametes, or reproduction resulting from such artificial fertilisation except where a law provides otherwise or a court so orders."

Furthermore, in terms of the definition of "parent" in section $1^{17}$ and section $26(2)(b)^{18}$ of the Children's Act, men who only contribute gametes to the production of a child do not acquire parental responsibilities and rights. These individuals are, as such, prohibited from claiming paternity and parental rights on this basis alone. The position ostensibly differs where individuals are able to provide additional proof of parenthood, in which case

11 Picciuto "Have Sperm, Will Travel: The 'Natural Inseminators' Helping Women Avoid the Sperm Bank" (undated) https://www.thedailybeast.com/have-sperm-will-travel-the-naturalinseminators-helping-women-avoid-the-sperm-bank (accessed 2019-06-19).

12 See Anonymous "Appropriate Contact and Maintenance Guidelines for Sperm Donors" 2017 De Rebus 51 and $R$ v S 2018 (5) SA 308 (KZD).

13 While the South African Law Reform Commission in Issue Paper 32 (Project 140) is investigating the right to know one's own biological origins with a view to law reform, the legal position regarding donor anonymity remains unchanged in the interim.

$14 S$ 41(1) of the Children's Act limits the information to which a child born by means of gamete donation may have access. This provision states: "A child born as a result of artificial fertilisation or surrogacy or the guardian of such child is entitled to have access to-

(a) any medical information concerning that child's genetic parents; and

(b) any other information concerning that child's genetic parents but not before the child reaches the age of 18 years."

15 GN 1165 in GG 40312 of 2016-09-30.

61 of 2003.

17 "Parent" is defined as excluding "any person who is biologically related to a child by reason only of being a gamete donor for purposes of artificial fertilisation" (s 1 of the Children's Act).

18 S 26(2)(b) of the Children's Act excludes a person who is only a gamete donor from claiming paternity. 
they may acquire parental responsibilities and rights. ${ }^{19}$ This was confirmed in $R \vee S .20$

\section{4 \\ $R$ v S 2018 (5) SA 308 (KZD)}

$R v S$ is the first reported South African decision dealing with known sperm donation. The facts of this case are as follows: the respondent, $S$, gave birth to a son, E, who had been "naturally conceived" with the applicant, R. The application before the court was one in which the applicant sought full parental responsibilities and rights in respect of his "donor-conceived" son on the basis of section 21(1)(b) of the Children's Act. ${ }^{21}$

Prior to the birth of their son, the parties had been romantically involved and had even cohabited for some time until their relationship ended. ${ }^{22}$ In 2014, the respondent approached the applicant asking him to "impregnate her through natural insemination", although no obligations would be imposed on him. ${ }^{23}$ The respondent averred that she merely wanted her child to know his biological origins. ${ }^{24}$

During her pregnancy, the applicant however attended prenatal doctor's visits and scans with the respondent, contributed towards the costs of some of these visits as well as lying-in expenses for the respondent. He further attended antenatal classes with the respondent and was registered as the father on the minor's birth certificate. ${ }^{25}$ Thereafter, he had contact with the child on terms decided by the respondent. He attended paediatrician checkups with the respondent. He even took $E$ to visit his paternal grandmother. In addition, he offered to pay maintenance. ${ }^{26}$ At some point, however, the respondent decided to limit the amount of interaction between the applicant and $\mathrm{E}$. This resulted in his requesting that a parenting plan be concluded to formalise the arrangement between them. In response to this request, the respondent alleged that "the appropriate" agreement between the parties amounted to a "known donor agreement" and as such he was not entitled to parental responsibilities and rights that would permit him to conclude a

19 In terms of $s$ 21(1) of the Children's Act, an unmarried father may acquire full parental responsibilities and rights, or he may apply for contact with the child in terms of $s 23$ of the Act.

20 Supra.

$21 \quad R \quad$ S supra par 9(a). S 21(1)(b) states: "The biological father of a child who does not have parental responsibilities and rights in respect of the child in terms of section 20 , acquires full parental responsibilities and rights in respect of the child-

(b) if he, regardless of whether he has lived or is living with the mother-

(i) consents to be identified or successfully applies in terms of section 26 to be identified as the child's father or pays damages in terms of customary law;

(ii) contributes or has attempted in good faith to contribute to the child's upbringing for a reasonable period; and

(iii) contributes or has attempted in good faith to contribute towards expenses in connection with the maintenance of the child for a reasonable period."

$R v S$ supra par 9(b).

$R v S$ supra par $9(\mathrm{e})$

$R \vee S$ supra par $9(\mathrm{~d})$.

$R \vee S$ supra par $9(\mathrm{f})-(\mathrm{h})$ and $(\mathrm{k})$.

$R \vee S$ supra par $9(\mathrm{~m}),(\mathrm{o}),(\mathrm{q}),(\mathrm{s})$ and $(\mathrm{u})$. 
parenting plan with the respondent. ${ }^{27}$ She averred that while such agreements were novel in South Africa and were not expressly recognised by law, the law should be developed in recognition of her constitutional rights to dignity and sexual preference and her choice of single motherhood as a chosen family structure. ${ }^{28}$

The court found that given the level of involvement by $\mathrm{R}$, he qualified for parental responsibilities and rights as he was not merely a gamete donor. ${ }^{29}$ On the question of whether parental responsibilities and rights could be excluded in agreements with known sperm donors, the court was unwilling to decide whether these agreements were legal. ${ }^{30}$ Within the South African context, this question thus remains unanswered.

\section{CURRENT TRENDS INVOLVING INFORMAL AGREEMENTS WITH KNOWN SPERM DONORS}

Globally, views regarding sperm donation differ vastly. In Sweden and the UK, anonymous sperm donation is banned, with Sweden becoming the first country to outlaw the practice in $1985 .{ }^{31}$ Since then, a number of countries have followed suit. These include Austria, ${ }^{32}$ Germany, ${ }^{33}$ Switzerland, ${ }^{34}$ parts of Australia, ${ }^{35}$ the Netherlands, ${ }^{36}$ Norway, ${ }^{37}$ New Zealand ${ }^{38}$ as well as Ireland. ${ }^{39}$

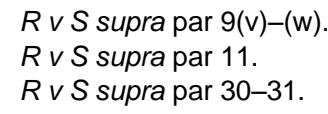

30 $R \vee S$ supra par 15-16. The reason advanced by Koen $\mathrm{J}$ for not deciding the question was the fact that in the absence of detailed argument on the subject, he did not feel the need to address the issue as a separate legal concern.

31 Donor anonymity in Sweden was abolished with the promulgation of the Act on Insemination (SFS 1984:1140), which has since been repealed. See Stoll "Establishing Paternity by Court Judgment Following Sperm Donation: Some Reflections on Two Judgments Rendered by the Svea Court of Appeal" in Jänterä-Jareborg, Maarit; Brattström, Margareta (ed.) För barns bästa: Vänbok till Anna Singer (2017) 317-344 318.

32 In Austria, donor-conceived children gained access to donor information when the Reproductive Medicine Law, Law No. 275, was passed on 1 July 1992.

33 Donor Offspring Europe notes that Germany recognised the right of individuals to know their genetic origins as part of their constitutional rights in $1988 \mathrm{http}: / /$ donoroffspring.eu/countryreports/germany/ (accessed 2020-10-22).

34 Anonymous sperm donation has been banned in Switzerland since the amendment of the Constitution in 1992. The incorporation of article 24 into the Constitution recognised the rights of individuals to know their genetic origins, which includes donor-conceived children.

35 Victoria passed the Infertility Treatment Act in 1995 and Western Australia reviewed its Human Reproductive Technology Act in 1999 to abolish donor anonymity.

36 The Netherlands passed the Donor Information Insemination Act (Wet donorgegevens kunstmatige bevruchting, 2002), which allowed for non-anonymous sperm donation since 2004.

37 This is in terms of the Biotechnology Act, No. 100 of 5 December 2003.

38 The Human Assisted Reproductive Technology Act 2004, which entered into force on 22 August 2005, provided that all sperm donations must be non-anonymous.

39 The Children and Family Relationships Act 2015 entered into force in 2015 and effectively prohibits donor anonymity. 
In contrast, the United States of America and Spain continue to offer anonymous sperm donation 40 - although a large number of fertility clinics in these countries offer donor recipients the option of using gametes from known sperm donors. ${ }^{41}$

Where known sperm donation occurs by means of artificial fertilisation, the legal position is that donors are not legal parents. ${ }^{42}$ In contrast, where insemination occurs naturally or outside the clinic setting and an informal agreement has been reached, donors are increasingly being recognised as legal parents. ${ }^{43}$ This is evident from developments in countries such as Australia, the USA and Canada.

\section{Australia}

The year 2019 saw the end of a five-year-long legal battle between a sperm donor and a lesbian woman who had been artificially inseminated in 2006 and later gave birth to a baby girl. According to the donor, the parties allegedly agreed that he would be involved in the child's upbringing. He was listed as her father on her birth certificate and she even called him "Daddy". The mother, who had entered into a new relationship, wanted to move to New Zealand with the child. The "donor" opposed the move and asked that his parental rights be recognised. ${ }^{44}$ The High Court ruled in his favour, finding that he qualified as a father rather than as a known sperm donor. ${ }^{45}$

This judgment is extraordinary, as mere involvement in a child's life does not normally equate to an entitlement to parental rights. ${ }^{46}$ However, in this case, the court interpreted this differently based on the level of the applicant's involvement. These facts clearly contributed to the court reaching the decision that it did. What is worth noting in this case is that the court attached some value to the applicant's intention to parent, even though artificial insemination had taken place. However, this decision, while lauded by some, failed to clarify the extent of involvement needed in order to qualify individuals for parental rights in other situations. ${ }^{47}$

40 This may be attributed to the absence of federal regulation on the subject. Cohen, Coan, Ottey and Boyd "Sperm Donor Anonymity and Compensation: An Experiment With American Sperm Donors" 2016 Journal of Law and the Biosciences 471. In Spain, the situation is regulated by Law 14/2006-Human Assisted Reproduction Techniques, which entered into force in May 2006. See, for e.g., Melo-Martin "How Best to Protect the Vital Interests of Donor-Conceived Individuals: Prohibiting or Mandating Anonymity in Gamete Donations?" 20163 Reproductive Biomedicine \& Society Online 100101.

41 Clark "A Balancing Act? The Rights of Donor-Conceived Children to Know Their Biological Origins" 2012 40(3) Georgia Journal of International and Comparative Law 619639.

42 See fn 1 above.

43 In terms of Irish law, sperm donors who are involved in home insemination qualify as fathers. See O'Loughlin "Fertility Struggles: Irish Women Are Buying Sperm Online and Inseminating Themselves at Home" (10 November 2019) https://extra.ie/2019/11/10/ lifestyle/health/women-buying-sperm-online-inseminating (accessed 2020-03-08).

44 Masson v Parsons [2019] HCA 2119 June 2019 S6/2019 par 4.

45 Masson $v$ Parsons supra par 24.

46 Masson $v$ Parsons supra par 25. In the earlier decision before the Family Court, the court found that the appellant was not a parent.

47 See "Can a Sperm Donor Be a Legal Parent? In Landmark Decision, the High Court Says Yes" (2019-06-19) The Conversation https://theconversation.com/can-a-sperm-donor- 
Based on this judgment, use of artificial insemination where the sperm donor is known is not a primary consideration. Instead, other factors, such as active involvement in the child's life, may feature more prominently.

\section{United States}

In 2007, the Kansas Supreme Court was confronted with a question regarding the status of a known sperm donor in the case of In the interest of $\mathrm{KMH}$ and $\mathrm{KCH} .{ }^{48}$ At the time of artificial insemination (Al), the parties had failed to enter into a written contract, although the donor claimed that an oral agreement had been concluded that permitted him to assume the role of father to any children born as a result of Al. ${ }^{49}$ Following the birth of the twins, the mother sought a court order confirming that the donor did not enjoy any parental rights. ${ }^{50}$ The defendant in turn sought an order seeking joint custody. ${ }^{51}$ At the time, Kansas law provided that sperm donors, in the absence of a written agreement stating the contrary, did not acquire parental rights in respect of children born from their donations. ${ }^{52}$ The court found in the mother's favour. ${ }^{53}$ The absence of a written agreement was clearly a deciding factor in this case, although Al was performed by a physician. ${ }^{54}$

In the same year, in Ferguson v McKiernan, ${ }^{55}$ the Pennsylvania Supreme Court considered the same question in circumstances that were somewhat different. In this case, the parties had had a previous sexual relationship. They later agreed that McKiernan would donate sperm to Ferguson, but he would not have any parental rights in respect of the twins and would not have any contact with them. ${ }^{56}$ However, five years after the twins' birth, Ferguson instituted a claim against McKiernan for child support. ${ }^{57}$ The trial court had found in the mother's favour. ${ }^{58}$ It concluded that while the existence of the agreement between the parties had been proved, it would

be-a-legal-parent-in-landmark-decision-the-high-court-says-yes-115553 (accessed 201906-23); and Anonymous "Sperm Donor is Child's Legal Father, Australian Court Rules" (2019-06-19) https://www.bbc.com/news/world-australia-48686216 (accessed 2019-06-20).

(Kan. 2007).

KMH and $\mathrm{KCH}$ supra 1029

50 Ibid. She alleged that "the donor had no parental rights under Kansas law". The basis of her petition is that the parties had not agreed beforehand that he would acquire parental responsibilities in respect of the children born from his donation.

$51 \mathrm{KMH}$ and $\mathrm{KCH}$ supra 1030. He also expressed his commitment to maintain his children in compliance with his legal obligations as their father.

52 See s 38-1114(f) of the Kansas Code 2006, which states: "The donor of semen provided to a licensed physician for use in artificial insemination of a woman other than the donor's wife is treated in law as if he were not the birth father of a child thereby conceived, unless agreed to in writing by the donor and the woman."

$53 \mathrm{KMH}$ and $\mathrm{KCH}$ supra 1042-1043.

54 Conversely, in Jhordan C v Mary K 179 Cal.App.3d 386 (Cal. Ct. App. 1986) where the child had been conceived by means of natural insemination, the court concluded that the sperm donor qualified for parental rights.

55940 A.2d 1236 (Pa. 2007).

56 Ferguson v McKiernan (2007) supra 1246.

57 Ferguson v McKiernan (2007) supra 1238.

58 Ferguson v McKiernan 855 A.2d 121 (Pa.Super.2004). In terms of the order granted on 31 December 2002, McKiernan was recognised as the legal father of twin boys born as a result of in vitro fertilisation (IVF) and was therefore obligated to pay child support. 
allow her claim for child support as the agreement was against public policy and therefore unenforceable as it was contrary to the children's best interests. ${ }^{59}$ This decision was confirmed on appeal.60 On a further appeal, the Supreme Court overturned the previous decisions, finding that where parties enter into sperm donor agreements, whether in a clinical or private setting, these agreements are enforceable and not against public policy despite the impact on the children's best interests. ${ }^{61}$ Here, much emphasis was placed on the intention of the parties. ${ }^{62}$ The decision was further bolstered by the fact that the donor was not involved in the children's lives at all 63 and had since gone on to have his own child, who would be severely prejudiced by a decision ordering the donor to pay child support. ${ }^{64}$

In this case, consideration was thus given to the interests of all parties, including the best interests of the children born from the donation, and those of the donor's other child. What is worth noting is that the court observed that the method of conception is not a primary factor in disputes of this nature. ${ }^{65}$ If one can thus exclude parental responsibilities and rights by making use of a fertility centre, then one should also be able to do so in the case of conception elsewhere. The level of involvement and the intention of the parties are pivotal in these cases. The decision in this case provides an answer to the question that the court omitted to answer in $R v S .{ }^{66}$

In Kansas $v W M, 67$ a lesbian couple, Bauer and Schreiner posted an advertisement on Craigslist seeking a sperm donor. William Marotta responded and the parties subsequently signed an agreement whereby Marotta relinquished all parental rights to a child born from the donation. He delivered his sperm to the couple's home and they then engaged in home insemination to fall pregnant. A daughter was later born from the donation.

A number of years later, the relationship between Bauer and Schreiner ended. Schreiner subsequently contracted an illness and applied for state funding to care for her daughter. However, Kansas law required the identity of the child's biological father to be disclosed before a child could qualify for state funding. Kansas law further stated that where artificial insemination is performed outside a clinic setting, the sperm donor acquires parental responsibility and rights. The state thus wanted to hold Marotta liable for child support. It argued that the sperm donor agreement concluded with Bauer and Schreiner was invalid and as such Marotta qualified as a parent,

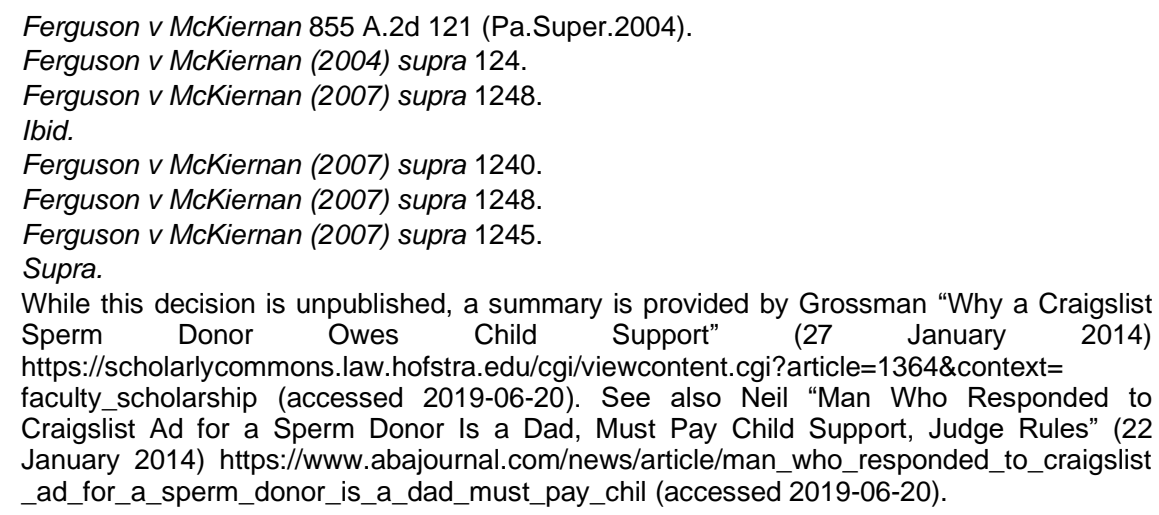


which imposed an obligation on him to maintain the child. Here a lack of intention to parent and the absence of involvement carried no weight. Instead, the court focused solely on the mode of insemination. ${ }^{68}$

This decision has since been overturned. ${ }^{69}$ On appeal, the court found that Mr Marotta's lack of involvement in the child's life was indicative of his intention not to be a parent. ${ }^{70}$

\section{Canada}

In 2017, a Canadian court in MRR $v J M^{71}$ had to decide a dispute between applicant MRR and respondent JM, who had had a previous sexual relationship. While their relationship had terminated, they remained friends. In 2012, MRR tried unsuccessfully to reproduce using anonymous sperm donation. Upon hearing his, JM offered to assist. Conception occurred by means of sexual intercourse, allegedly after MRR's failed attempts using artificial fertilisation. ${ }^{72}$

Prior to conception, the parties allegedly agreed that, if MRR fell pregnant, JM would not acquire any parental responsibilities and rights in respect of the child. However, this agreement was only confirmed in writing nine months after JRR had been born. ${ }^{73}$ Nonetheless, MRR brought an application for child support soon thereafter. ${ }^{74}$ She argued that although the parties had originally agreed that $\mathrm{JM}$ would not be a parent, their intentions had since changed. ${ }^{75}$ Apparently JM treated the child as his and in light of

68 Judge Mattivi ruled: "Kansas law is clear that a 'donor of semen provided to a licensed physician for use in artificial insemination of a woman other than the donor's wife is treated in law as if he were not the birth father of a child thereby conceived, unless agreed to in writing by the donor and the woman.' ... This court finds that, because the parties did not provide the donor sperm to a licensed physician, the statutory basis for preclusion of paternity does not apply, and the donor therefore can be determined to be the father of the child." WUNC 91.5 North Carolina Public Radio "Court to Sperm Donor: You Owe Child Support" (12 February 2014) https://www.wunc.org/post/court-sperm-donor-you-owe-childsupport (accessed 2020-10-27). In this instance, the fact that insemination was performed at home meant that Marotta could not be considered a sperm donor under state law and was found to be the child's presumptive father instead (Starza-Allen "Craigslist Sperm Donor Not Legally Child's Father" (2 December 2016) https://www.bionews.org.uk/page_95806 (accessed 2020-10-22)).

69 On 22 November 2015, the court ruled that the birth mother's former partner should be considered the child's second parent rather than Marotta. The reason for this was partly because he had had minimal contact with the child. CBS Sacramento "Judge: Sperm Donor Who Helped Lesbian Couple Doesn't Owe Child Support" (1 December 2016) https://sacramento.cbslocal.com/2016/12/01/judge-sperm-donor-who-helped-lesbiancouple-doesnt-owe-child-support/ (accessed 2020-10-10).

70 See Anonymous "Craigslist User Who Donated His Sperm to a Lesbian Couple for $\$ 50$ so They Could Have a Baby Will Not Have to Pay Child Support After Judge Rules He Is Not the Child's Legal Father" (29 November 2016) Mail Online https://www.dailymail.co.uk/ news/article-3983756/Kansas-judge-rules-sperm-donor-not-hook-child-support.html (accessed 2019-06-20).

2017 ONSC 2655.

72 MRR $v$ JM supra par 6-8.

73 MRR $v$ JM supra par 9 and 25.

74 MRR $v$ JM supra par 10.

75 MRR allegedly withdrew her offer before JM signed it and it is accordingly invalid (par 13). 
this, the child should not be deprived of child support. ${ }^{76} \mathrm{JM}$, in turn, argued that his intention had not changed and that he had no desire to be a father. ${ }^{77}$

Justice Fryer found that JM is presumed to be the father of the child since conception had occurred naturally. ${ }^{78}$ The basis of this decision was section 7(1) of the Children's Law Reform Act 1990, which states that where conception occurs through sexual intercourse, a sperm donor is legally recognised as the parent of a child. The exception to this rule only applied to persons who had confirmed in writing before conception had taken place that they did not intend to parent. ${ }^{79}$ Because JM delayed signing the agreement, the exception did not apply to him. ${ }^{80}$ The court nonetheless found that he was not a parent based on his pre-conception intention, which had not changed. ${ }^{81}$

\section{LESSONS LEARNT}

From the aforementioned cases, a number of lessons can be learnt.

\section{The legality of known sperm donor agreements}

The decision in Ferguson $v$ McKiernan ${ }^{82}$ supports the opinion that agreements with known sperm donors should be viewed as legal. ${ }^{83}$ If one can exclude parental responsibilities at a clinic, then the same should apply where artificial insemination occurs outside the clinic setting, provided that an agreement is concluded using the services of legal practitioners who will make provision for the interests of the potential child. This, in the author's opinion, should be the overriding concern. In $R v S$, no such agreement had been concluded but, had this been the case, $S$ should have been able to enforce her rights. ${ }^{84}$ It is only regrettable that she wished to enjoy the benefits of having a co-parent without awarding him the rights that accompany parenthood.

\section{The distinction between sexual and assisted reproduction}

In Ferguson $v$ McKiernan, ${ }^{85}$ the court also indicated that no distinction should be made between whether reproduction occurs by means of sexual

MRR $v$ JM supra par 12.

MRR v JM supra par 27 and 88.

MRR $v$ JM supra par 61-62.

The exception is provided for in s 7(4) of the Children's Law Reform Act.

MRR $v$ JM supra par 82.

MRR v JM supra par 135. In par 130 Fryer J added: "It is conceivable that in certain cases, the actions of the parties following the conception of the child could be so different from the pre-conception intentions that a declaration of non-parentage would not be appropriate. However, the overall legislative purpose of Part I of the (Children's Law Reform Act) suggests that the parties' pre-conception intent is to be given significant weight."

82940 A.2d 1236 (Pa. 2007).

83 Ferguson v McKiernan (2007) supra 1248.

84 In particular, her rights to choose single motherhood as a chosen family structure.

85 Ferguson v McKiernan (2007) supra. 
intercourse or artificially. ${ }^{86}$ In South Africa, the fall-back position has always been that where reproduction occurs sexually, parental responsibilities and rights are generally applicable, whereas with artificial fertilisation they are not. ${ }^{87}$ Given the manner in which the world has developed, is this distinction still valid? Should men (or women for that matter) be able to engage in sexual intercourse that results in pregnancy and then claim it was a donation, so releasing "the donor" from all responsibility? It is submitted not. Entering into a sperm donor agreement before conception occurs still provides all parties concerned with some level of protection. In this respect, the court in $R \vee S$ was correct in finding that the agreement between the parties did not qualify as a sperm donor agreement and that the donor was in fact a father. ${ }^{88}$

\section{Factors that are prioritised}

The level of involvement in a child's life appears to receive the most attention from courts in deciding whether or not a donor qualifies as a father. This factor serves as evidence of intention to parent. Where there is active involvement in the child's life, a court is reluctant to find that the donor is just that. In such cases, courts base their decisions on the fact that removing an active participant from the child's life would not be in the child's best interests.

The second factor that plays a decisive role is the existence of an agreement between the parties. Where such an agreement exists, courts attempt to abide by the agreement in recognition of the parties' autonomy. The method of reproduction, although also a factor, seems to be of least importance.

\section{The best interests of the child}

From the cases considered above, courts have found that, where a donor was involved in the child's life, it is in the child's best interests for him to be recognised as a legal parent. The converse is also true. What is equally true is that courts may set aside a valid sperm donor agreement if it is in the best interests of the child to do so. The Australian decision of Re Patrick is one example of this approach. 89

The challenge posed by applying the best interests' principle is that a man with no intention to parent may be foisted with parental responsibilities and rights and a woman may be saddled with a co-parent when it was never her intention. In $R \vee S$, the respondent urged the court to have regard to her

36 Ferguson v McKiernan (2007) supra 1245.

87 The only exceptions to this are where the child is a result of rape or incest. In these cases, the father will not acquire parental responsibilities and rights. These exceptions are provided for in the definition of "parent" in s 1 and s 26(2)(b) of the Children's Act.

$88 \quad R v S$ supra par 2, 10,13 and 14.

89 [2002] FamCA 193. In this case, the court per Guest $J$ found that while the sperm donor was not a parent, he qualified for contact with the child. The mother, who was unable to deal with the sperm donor's increased role in her child's life, subsequently killed herself and the child. 
constitutional rights to dignity and sexual preference and her choice of single motherhood as a chosen family structure. ${ }^{90}$ In genuine cases involving agreements with known sperm donors (unlike the one in $R \vee S$ ), such a concern is valid. In South Africa, the Constitution recognises the rights of individuals to equality, which includes the right not to be discriminated against on the basis of marital status, conscience or belief. ${ }^{91}$ Choosing to be a single parent is an expression of this right. The Constitution further recognises the right of individuals to make decisions concerning reproduction. ${ }^{92}$ This includes deciding when to reproduce and how to do so. Yet, despite the existence of these rights, South African courts are increasingly finding that the rights of (prospective) parents may be justifiably limited in the interests of the (potential) child. ${ }^{93}$ This suggests that there may be a perception that the choice to be a single parent is contrary to the child's best interests. ${ }^{94}$ This leaves single parents in a compromised position: where their rights are viewed as secondary to that of their potential offspring. This undermines the prospective parent's autonomy.

It is perhaps for this reason that it is better for parties to confirm their agreements before conception takes place and to abide by the terms thereof. While there is no guarantee that a court may not override such an agreement, it is better for prospective parents to err on the side of caution.

\section{Prejudice to single and lesbian women}

Regrettably, situations where disputes arise involving known donors more frequently involve single and lesbian women. ${ }^{95}$ Cases have yet to be reported where an egg donor claims parental responsibilities and rights in respect of a child born. ${ }^{96}$ This raises an interesting question: do women engage in behaviour that renders them more vulnerable to claims of this nature or does the problem lie with the donors who fail to obtain clarity about their roles prior to fertilisation? ${ }^{97}$ Case law on this subject seems to suggest that the problem lies on both sides. So, what is the solution?

$90 \quad R v S$ supra par 11.

91 Van der Walt "The Meaning of (Unfair) Discrimination: Constitutional Law" 2019 19(5) Without Prejudice 36-37.

92 Van Niekerk "Assisted Reproductive Technologies and the Right to Reproduce Under South African Law" 2017 20(1) PELJ/PER 15.

93 AB v Minister of Social Development 2017 (3) SA 570 (CC) and Ex parte CJD 2018 (3) SA 197 (GP) both serve as evidence. In the former case, the court found that a divorcee's right to reproductive autonomy may be limited, and, in the latter case, the court found that the second applicant's right to conceal his sexual orientation was not in the child's best interests. It accordingly declined to confirm the surrogacy agreement.

94 Pimentel "Protecting the Free-Range Kid: Recalibrating Parents' Rights and the Best Interest of the Child" 201638 Cardozo L. Rev. 1.

95 As opposed to married couples and single or gay men.

96 This is because donors donate their eggs and then relinquish their rights to them. However, the position is different where the egg donor is also the surrogate. In certain jurisdictions, such as the United Kingdom, the surrogate is viewed as the legal mother until a parental order is granted to the commissioning parents. See Hodsen and Bewley "Parental Orders and the Rights of Surrogate Mothers" 2018 Royal College of Obstetricians and Gynaecologists 352.

97 Riggs "Lesbian Mothers, Gay Sperm Donors, and Community: Ensuring the Well-Being of Children and Families" 2008 17(3) Health Sociology Review 228. 


\section{THE WAY FORWARD}

In instances where fertilisation occurs with the intervention of a licensed medical practitioner and a fertility centre, the legal position is regulated and therefore clear. Problems arise where fertilisation does not occur in this manner. The reality remains that individuals are likely to continue to determine their own path to parenthood without the intervention of licensed medical practitioners and fertility centres. There is a need to provide some guidelines for those who opt for this route (either by making use of a turkey baster ${ }^{98}$ or by sexual reproduction). The following is thus proposed:

1. The focus on the place of fertilisation as an indication whether someone qualifies as a legal parent or donor should fall away. ${ }^{99}$ The deciding factor should be the intention of the parents before fertilisation takes place.

2. The term "known sperm donor" should be more broadly defined. Such definition should include a male who is known to the recipient, either intimately or otherwise, and who acts as her donor at her request. ${ }^{100}$ The distinction between a known donor and a single father should be clear. Among other indicators, the known donor should not provide the recipient with financial support, nor refer to the child as "his", and should have contact only as agreed upon between the parties.

3. The timing of the conclusion of the agreement and the consequences thereof should be clarified. Ideally, all agreements should be concluded before fertilisation takes place. Where such agreement is concluded after fertilisation, the following distinction should apply:

a. In cases where fertilisation has occurred, but the child is not yet born, the agreement can apply retrospectively; alternatively,

b. In cases where fertilisation has occurred and a child has subsequently been born, regard must be had to the intention of the parties as well as their subsequent actions to determine what is in the child's best interests. Where there has been minimal contact between the donor and the child, the mother's rights should be prioritised. However, where there has been substantial contact, the child's rights should be prioritised. That said, courts should avoid imposing a heteronormative family model where this was never the desire of the commissioning

98 The turkey baster method is a technique of artificial insemination (intracervical insemination) practised by the woman herself, usually in the comfort of her own home. It involves the collection of sperm that can either come from a sperm bank or from a known donor. After being collected, the semen is slowly injected with a syringe as close to the cervix as possible in order for the sperm to fertilise the egg. Many women find this method of becoming pregnant at home useful (CoParents.com "The Turkey Baster Method: What It Is and How to Perform It" https://www.coparents.com/blog/the-turkey-baster-method-what-is-itand-how-to-perform-it/ (accessed 2020-10-22)). Also see BabyMed "At-Home Artificial Insemination: The Turkey Baster Method" https://www.babymed.com/home-artificialinsemination-get-pregnant-turkey-baster-method (accessed 2020-22-10).

99 Nadraus ("Dodging the Donor Daddy Drama: Creating a Model Statute for Determining Parental Status of Known Sperm Donors" 2015 53(1) Family Court Review 180 192) suggests that "failure to use a physician to assist in the insemination process [should] not be determinative in establishing parental rights or obligations to the resulting child".

100 According to s 68-3-306 of the 2014 Tennessee Code, a "known donor" is defined as "a donor who the inseminated woman knows and chooses to be her donor at her request". 
parent. An outcome similar to that of Re Patrick should be avoided at all costs. ${ }^{101}$

4. The donor's rights and obligations should be clearly defined. Where there is an intention to parent, the status of the donor should be in question.

5. It should be required that a known sperm donor agreement be in writing. Where this requirement is lacking, a donor should be required to provide proof that he qualifies for parental responsibilities and rights. ${ }^{102} \mathrm{Here}$, the court should consider:

a. the relationship between the parties before conception and thereafter;

b. evidence of an oral agreement;

c. the level of contact that the donor has with the child;

d. the level of financial commitment of the donor towards the child;

e. the child's opinion on the donor's role in his/her life. ${ }^{103}$

Of the requirements listed, the level of contact with the child should be the overarching consideration. Someone with an active role in the child's life should be recognised. At the same time, parties should be clear about their intentions before concluding such agreements and should abide by the terms thereof to avoid being foisted with responsibilities that they do not desire. This prevents the child suffering from the removal from their lives of individuals who should not have played a role to begin with.

It is hoped that implementing these guidelines will go a long way to avoiding some of the concerns that inevitably arise with disputes of this nature.

See heading 64 above.

102 For example by meeting the requirements of $s 21(b)$ of the Children's Act.

103 Some of the factors listed here are already contained in s 23 of the Children's Act, which deals with "the assignment of contact and care to [an] interested person by order of court". However, Nadraus (2015 Family Court Review 192) suggests additional factors that may be considered. 